\title{
Late Silurian palynomorphs from the Precordillera of San Juan, Argentina: Diversity, palaeoenvironmental, and palaeogeographic significance
}

Victoria J. García Muro, Claudia V. Rubinstein, and Philippe Steemans

Acta Palaeontologica Polonica 63 (1), 2018: 41-61 doi:https://doi.org/10.4202/app.00400.2017

The palynological content from the Cerro La Chilca and Quebrada Ancha sections of the Wenlock? to Př́idolí Los Espejos Formation, in the Argentinean Precordillera is studied. The marine palynomorphs exhibit higher relative abundance and diversity in almost all the productive samples, except for the uppermost ones from both sections, in coincidence with the shift towards more proximal facies in this part. The Los Espejos Formation yielded a total of 114 species of marine organic walled-phytoplankton, 52 species of miospores and two non-marine phytoplankton species. The lower part of the Los Espejos Formation, dated as Ludfordian, displays the highest phytoplankton diversity and the better-preserved palynomorphs of the studied samples in both sections. Diversity tends to diminish towards the upper part of the Los Espejos Formation, dated as late Ludfordian-Př́dolí, in coincidence with the transition to storm-dominated shelf and shoreface environments and subaerial exposures that probably hinder the preservation of palynomorphs. Comparisons with coeval phytoplankton assemblages from Gondwana and other palaeoplates such as Laurentia, Baltica, and Avalonia result in strong similarities, which suggest a cosmopolitan distribution pattern during the Ludlow and the Prrídolí. Conversely, the trilete spores display more similarities with those from Gondwana and thus suggest a lesser dispersive potential in comparison to phytoplankton. A new trilete spore species Emphanisporites ? tenuis is described.

Key words: Organic walled-phytoplankton, miospores, abundance, diversity, palaeoenvironment, palaeobiogeography, Silurian, Argentina.

Victoria J. García Muro [vgarcia@mendoza-conicet.gov.ar] and Claudia V. Rubinstein [crubinstein@mendoza-conicet.gov.ar], IANIGLA, CCT CONICET Mendoza, Av. Ruiz Leal s/n, Parque General San Martín, CC:

M5502IRA, Mendoza, Argentina. Philippe Steemans [p.steemans@ulg.ac.be], Unité de Paléobiogéologie, Paléobotanique et Paléopalynologie, Dpt. de Géologie, Université de Liège, B18/P40 Quartier Agora, Allée du 6 Août, 14, Liège, Belgium. 
This is an open-access article distributed under the terms of the Creative Commons Attribution License (for details please see creativecommons.org), which permits unrestricted use, distribution, and reproduction in any medium, provided the original author and source are credited.

FoF Full text $(1,794.2 \mathrm{kB})$

FoF 